\title{
EFFECT OF CRUDE EXTRACT GARNEW ON PEACH AND GRAPE INFECTION WITH ROOT KNOT NEMATODE Moatamed, A. M. H. ${ }^{1}$ and Hanaa S. Zawam ${ }^{2}$ 1-Hortculture Research Institute 2- Plant Pathology Research Institute Agric. Res. Center, Giza-Egypt
}

\begin{abstract}
A pot experiment were carried out during two seasons of 2009/2010 and 2010/2011 under greenhouse conditions in the nursery of Hortculture Research Institute. Garnew crude extract of ( Artemisia, Garlic, Chrysanthemum, Menthe and Marjoram)

was tested to control the nematode infection of Meloidogyne incognita and Meloidogyne javanica on peach and grape. Three concentrations of Garnew were used ( $0.5 \%, 5 \%$ and $10 \%)$ to control the both nematode species on peach and grape. The most effective concentration of Garnew was $10 \%$. Whereas the nematicide ethoprop decreased the nematode soil population by $98.8 \%$ at the recommended dose and oxamyl decreased it by $98.1 \%$ at the recommended dose. Garnew decreased the number of galls, egg-masses and the developmental stages of the both nematode species on peach and grape by the same level of reduction. Results of plant growth parameters indicated that the highest concentration of Garnew (10\%) has appositive effect on plant growth. Mineral accumulation in the leaves or roots of both cultivars of peach and grape was differed according to the concentration of the treatment, but generally increased than the untreated plants. The total protein electrophoresed on one dimension SDS-PAGE revealed differences in the intensity of the same protein bands between the treated and untreated plants.

Keywords:Non fumigant nematicides, crude extract (Garnew), Meloidogyne spp., Peach, Grape, nutrient uptake, one dimension SDS-PAGE, total protein electrophoreses
\end{abstract}

\section{INTRODUCTION}

Nematodes are important pests in grapes and peach trees around the world, and these soil-borne pests can be particularly problematic in Egypt on peach and grape. Two factors intensify the impact of nematodes : the high value of grapes and of vineyard land costs. These factors force growers to ignore the steps of leaving land fallow and rotating crops, both of which reduce nematode build up and delay the selection of adapted strains. Nematicides and fumigants help in control nematodes, but the use of these pesticides has been greatly restricted. Plants are an important source of naturally occurring pesticides. Many compounds with nematicidal activity have been found in plants, including alkaloids, diterpenes, fatty acids, glucosinolates, isothiocyanates, phenols, polyacetylenes, sesquiterpenes and thienyls; ( Gommers, 1981; Chitwood, 2002). Many compounds with nematicidal activity have been isolated from species in the family Asteraceae(Gommers, 1981; Chitwood, 2002). Also, Allicin (an active nematicidal principle in garlic) has been isolated by Gupta and Sharmaj, 1993 and tested against Meloidogyne incognita infesting tomato, they found that 
juvenile mortality of $87-100 \%$ at $2.5-5.0 \mathrm{ppm}$ allicin was recorded within 72 h. Essential oils of some plants and/or their components have been tested for nematicidal activity in vitro and in soil( Chatterjee et al.,1982; SolerSerratosa et al., 1996; Oka et al., 2000). Recently, the antifungal and insecticidal activity of the essential oil of Chrysanthemum coronarium flowerheads has been reported (Perez and Pascual-Villalobos, 1999; Alvarez-Castellanos et al., 2001). the essential oil from Mentha spicata with a high content of carvacrol and thymol, was effective against M. javanica (Oka et al. 2000).

The aim of the proposed study included;

Evaluate the efficacy of the crude extract compound to reduce the number of nematode in soil and roots of plants

\section{MATERIALS AND METHODS}

The present study revealed the comparative efficacy of Garnew compound as crude extract comparing with nematicides (Ethoprop and Oxamyl) with two addition rates.

Table (1) : List of compounds tested in this investigation

\begin{tabular}{|lcc|}
\hline Compound & Structure & Application rates \\
\hline Ethoprop & Organophosphate & $40 \mathrm{Kg} / \mathrm{feddan}(1)$ \\
Oxamyl & Oximcarbamate & $8 \mathrm{Kg} / \mathrm{feddan}(2)$ \\
& & $800 \mathrm{Cm}^{3} / \mathrm{feddan}(2)$ \\
Garnew & $\begin{array}{c}\text { Crude extract of Artemisia, Garlic } \\
\text { Chrysanthemum, Menthe and Marjoram }\end{array}$ & $800 \mathrm{Cm}^{3} /$ feddan (2) \\
\hline
\end{tabular}

Three experiments were carried out to study the effect of crude extract on plant parasitic nematode Meloidogyne javanica, and Meloidogyne incognita. The first experiment was conducted to test the dosage rates using on peach cultivar (Mit Gammer) and grape cultivar (Superior) seedlings under green house conditions

$\left(25- \pm 2^{\circ} \mathrm{C}\right)$ to control the root-knot nematode .The experimental soil was collected from the ARC farm, Giza, Egypt. The soil texture was sandy clay . Black plastic bags $20 \mathrm{~cm}$ in diameter were used for our test filled with steam sterilized soil about five kilo per bag

\section{Nematode stock culture}

Nematode populations were maintained on tomato plants cv. Castle rock under greenhouse conditions. Plants were infected at 2-3 leaves stage by adding egg-masses to roots (one egg-mass per one plant for making pure culture from $M$. incognita and $M$. javanica in plastic cups) then covered with soil. After 60 days nematode egg-masses collected from each root by a needle, put in Petri dishes and put it in incubator for hatching at $25 \pm 2^{\circ} \mathrm{C}$ for a week. The hatched juveniles were collected daily.

To study the effect of Garnew on development of Meloidogyne sp. on peach cultivar Mit Gammer seedling ,forty plastic bags were cultivated by one year 
old seedlings of peach in steam sterilized sandy clay soil . Twenty plastic bags were inoculated by 2000 newly hatched larvae of $M$. incognita by boring the nematode suspension in holes around the roots of the peach seedlings. Other twenty plastic bags were inoculated by the same method by 2000 newly hatched larvae of M.javanica. The twenty plastic bags which inoculated by M.incognita were divided into four groups 3 of them treated by Garnew compound by the dosage of $(0.5 \%, 5 \%$ and $10 \%)$ and the other 5 bags left without treatment of Garnew and served as inoculated control. The same treatment were made by the plastic bags of M.javanica This experiment was repeated on grape cultivar Superior of one year old seedlings. After 90 days the plants were uprooted and the roots were washed free from the adhering soil particles. Number of galls, number of egg-masses per $5 \mathrm{gm}$ roots and number of nematodes in $250 \mathrm{~cm}^{3}$ soil and also the developmental stages inside the roots were determined.

Another pot experiment was conducted to explore the effectiveness of the crude compound Garnew to reduce Meloidogyne incognit on peach cultivar Mit Gammer and grape cultivar Superior seedlings comparing with two nematicides (ethoprop and oxamyl) by using two concentrations from each.

Forty plastic bags were cultivated by one year old seedlings of peach in steam sterilized sandy clay soil. The plastic bags were divided into 8 groups, 7 of them inoculated by 2000 newly hatched larvae of $M$. incognita by boring the nematode suspension in holes around the roots of the peach seedlings, and one group left without inoculation and served as control. Other 7 groups were divided into:

1-two groups treated by ethoprop by the recommended dose and 1/10 of the recommended.

2-two groups treated by oxamyl by the recommended dose and 1/10 of the recommended.

3- two groups treated by Garnew by the recommended dose and 1/10 of the recommended.

4- one group left without treatment and served as inoculated control.

This experiment was repeated on grape cultivar Superior of one year old seedlings.

After 90 days the plants were uprooted and the roots were washed free from the adhering soil particles. Number of galls, number of egg-masses per $5 \mathrm{gm}$ roots and number of nematodes in $250 \mathrm{~cm}^{3}$ soil and also the developmental stages inside the roots were determined. Also, plant growth parameters, shoot length, shoot weight and root weight were determind for both peach and grape cultivars. Also, the number of new branches for peach was recorded. The plant analysis and total protein electrophoresis from this experiment determined according the following methods:

Plant analysis:

Samples of the fourth top leaves and secondary roots were taken and oven dried at $70^{\circ} \mathrm{C}$ for $48 \mathrm{hrs}$ and kept for chemical analysis.

A wet digested according to the methods of Tomas et al., (1967). In the digest solution $\mathrm{N}, \mathrm{P}, \mathrm{K}, \mathrm{Fe}$ and $\mathrm{Mn}$ were analyzed according to the following methods : 
1- Total nitrogen \% was determined by the distillation in a macrokjeldahl apparatus (Helrich, K. 1990)

2- Phosphorus \% was calorimetrically determined as described by Ranganna (1979

3- Potassium \% was determined photometrically using flame photometer, as described by Ranganna(1979)

4- $\mathrm{Ca}, \mathrm{Fe}, \mathrm{Mg}, \mathrm{Mn}, \mathrm{Na}$ and $\mathrm{Zn}$ were determined using Atomic Absorption Spectrophotometer PERKIN ELEMER 3300 according to Chapman and Pratt (1981)

All treatments of greenhouse experiments were statistically arranged in a complete randomize design according to Snedecor and Cochran (1989), where mean values were compared using L.S.D. at $5 \%$ level.

\section{Electrophoresis studies:}

Total protein analysis

Three grams of plant root samples were ground in precooled mortar and pestle with liquid nitrogen to a fine powder then $0.7 \mathrm{ml}$ of extraction buffer $(0.6 \mathrm{ml} 1 \mathrm{M}$ Tris $\mathrm{HCl} \quad \mathrm{pH} 6.8,5 \mathrm{ml} 50 \%$ glycerol , $2 \mathrm{ml} 10 \% \mathrm{SDS}, 0.5 \mathrm{ml} \beta$ mercaptoethanol and $0.9 \mathrm{ml} \mathrm{H}_{2} \mathrm{O}$ ) was added and the extracts were clarified by centrifugation at $14000 \mathrm{xg}$ for 15 minutes under cooling. The supernatants were transferred in fresh ependorf tubes and stored at $-20^{\circ} \mathrm{C}$. Supernatants containing soluble proteins fractions were transferred to clean tubes and stored at $-20^{\circ} \mathrm{C}$. Protein content was estimated according to the methods of Bradford (1976) using Bovine Serum Albumin (BSA) as a standard. Protein content was adjusted to $2 \mathrm{mg} / \mathrm{ml}$ per sample. SDS was added to the sample at the rate of $4 \mathrm{mg} \mathrm{SDS} \mathrm{/} 1 \mathrm{mg}$ protein, then $50 \mu \mathrm{l}$, B- mercaptoethanol were added. The mixture was boiled at $100^{\circ} \mathrm{C}$ in a water bath for 3-5 min. Vertical slab $(18 \times 16 \mathrm{~cm})$ gel electrophoresis apparatus was used as marketed by Hoofer (Hoofer SE 600 series Pharmacia). $20 \mu$ of this crude protein solution were resolved on $11 \%$ SDS - PAGE using molecular weight protein marker as a standard. Electrophoresis was carried out at 2 mille ampere per sample at $10{ }^{\circ} \mathrm{C}$ for $3 \mathrm{hrs}$. Gels were stained by silver staining method for protein as described by Sammons et al (1981). This method of staining is sensitive and detects as little as $2 \mathrm{ng}$ of protein in a single band. Gels were scanned for estimation molecular weight by using gel documentation system (AAB Advanced American Biotechnology 1166 E. Valencia Dr. Unit 6C, Fullerton CA, USA 92631). The different molecular weights of bands were determined against protein standard (Peqlab) marker.

\section{RESULTS AND DISCUSSION}

Plant-parasitic nematodes feed on grapevine roots and cause malformations or necrosis. This leads to destruction of physiologically active roots and an overall reduction in water and nutrient uptake. Above-ground parts of grapevines show no specific visual symptoms on leaves, shoots or fruits, but there is a general reduction in vigour. Similar symptoms could be due to, and confused with, other conditions 
such as poor physical characteristics of the soil, mineral excess or deficiency, water stress, or other soil-borne pests and diseases. Soil amended with crude extract Garnew offers a satisfactory and environmentally friendly compound for the control of root-knot nematode

Table ( 2 ) : Effect of Garnew on development of Meloidogyne sp. on peach Mit Gammer seedlings.

\begin{tabular}{|c|c|c|c|c|}
\hline \multirow{2}{*}{ Treatments } & & \multicolumn{3}{|c|}{ Nematode parameters (M.incognita) /root } \\
\hline & $\mathrm{J} 2 / 250 \mathrm{~cm}^{3}$ & No.galls/root & No.egg-masses & No.D.S/root \\
\hline M.incognita & 4200 & 2300 & 1700 & 1300 \\
\hline Garnew0.5\% & $3600^{*}$ & $1900^{*}$ & $1200^{*}$ & $980^{*}$ \\
\hline Garnew 5\% & $900^{*}$ & $470^{\star}$ & $300^{*}$ & $240^{\star}$ \\
\hline Garnew $10 \%$ & $350^{*}$ & $160^{*}$ & $70^{*}$ & $45^{*}$ \\
\hline \multirow[t]{2}{*}{ LSD 5\% } & 249.737 & 197.508 & 95.946 & 144.847 \\
\hline & & \multicolumn{3}{|c|}{ Nematode parameters (M.javanica) /root } \\
\hline M.javanica & 3090 & 1730 & 1360 & 990 \\
\hline Garnew0.5\% & $2700^{*}$ & $1500^{*}$ & $1080^{*}$ & $830^{*}$ \\
\hline Garnew 5\% & $850^{*}$ & $420^{*}$ & $340^{*}$ & $210^{*}$ \\
\hline Garnew $10 \%$ & $330 *$ & $180^{*}$ & $92^{*}$ & $53^{*}$ \\
\hline LSD 5\% & 75.804 & 36.930 & 159.131 & 29.503 \\
\hline
\end{tabular}

* means there is a significant effect at $5 \%$ level

Results in Table (2) indicated that there was a significant effect of the crude extract on all nematode parameters estimated with either $M$. incognita or M. javanica.

Table ( 3 ) : Effect of Garnew on development of Meloidogyne sp. on grape Superior seedlings.

\begin{tabular}{|c|c|c|c|c|}
\hline \multirow{2}{*}{ Treatments } & & \multicolumn{3}{|c|}{ Nematode parameters (M.incognita) /root } \\
\hline & $\mathrm{J} 2 / 250 \mathrm{~cm}^{3}$ & No.galls/root & No.egg-masses & No.D.S/root \\
\hline M.incognita & 5100 & 3250 & 2570 & 2400 \\
\hline Garnew0.5\% & $3800^{*}$ & $2350^{*}$ & $1860^{*}$ & $990^{*}$ \\
\hline Garnew 5\% & $890^{*}$ & $380^{*}$ & $430^{*}$ & $320^{*}$ \\
\hline Garnew $10 \%$ & $370^{*}$ & $210^{*}$ & $65^{*}$ & $38^{*}$ \\
\hline \multirow[t]{2}{*}{ LSD 5\% } & \multirow[t]{2}{*}{127.798} & 166.757 & 162.329 & 198.862 \\
\hline & & \multicolumn{3}{|c|}{ Nematode parameters (M.javanica) /root } \\
\hline M.javanica & 3600 & 1340 & 1210 & 1040 \\
\hline Garnew0.5\% & $2400^{*}$ & $900^{*}$ & $950^{*}$ & $720^{*}$ \\
\hline Garnew 5\% & $720^{*}$ & $330^{*}$ & $230^{*}$ & $110^{*}$ \\
\hline Garnew $10 \%$ & $230^{*}$ & $130^{*}$ & $60^{*}$ & $55^{*}$ \\
\hline LSD 5\% & 178.394 & 66.763 & 91.373 & 18.855 \\
\hline
\end{tabular}

* means there is a significant effect at $5 \%$ level

The same trend has been shown in Table (3) the reduction of juveniles in soil numberes of galls, egg-masses and different stages imbedded in the roots was gradually decreased as the concentration of the crude compound Garnew increased either for M. incognita or M. javanica . The effectivness of the crude compound Garnew was studied by comparing with the nematicides ethoprop and oxamyl using two doses on peach as showen in Table 4 
Table (4) : Effect of some treatments on development of Meloidogyne incognita in Peach ( Mit Gammer) seedlings.

\begin{tabular}{|c|c|c|c|c|c|c|c|c|}
\hline Treatments & $\mathrm{J} 2 / 250 \mathrm{~cm}^{3}$ soil & $\mathbf{R} \%$ & $\begin{array}{c}\text { No. } \\
\text { Galls/root }\end{array}$ & $\mathbf{R} \%$ & $\begin{array}{c}\text { egg- } \\
\text { masses } \\
\text { /root }\end{array}$ & $\mathbf{R} \%$ & $\begin{array}{c}\text { No. } \\
\text { D.S } \\
\text { /root }\end{array}$ & $\mathbf{R} \%$ \\
\hline Ethoprop1 & 48 & 98.8 & 25 & 98.3 & 23 & 97.6 & 41 & 95 \\
\hline Ethoprop2 & 2620 & 35.6 & 1152 & 23.2 & 500 & 48.5 & 113 & 86.2 \\
\hline Oxamyl1 & 76 & 98.1 & 42 & 97.2 & 31 & 96.8 & 50 & 93.9 \\
\hline Oxamyl2 & 2700 & 33.7 & 1400 & 6.67 & 620 & 36.1 & 217 & 73.5 \\
\hline Garnew 1 & 450 & 88.9 & 220 & 85.3 & 192 & 80.2 & 134 & 83.7 \\
\hline Garnew 2 & 700 & 82.8 & 340 & 77.3 & 221 & 77.2 & 161 & 80.4 \\
\hline Infected plant & 4070 & & 1500 & & 970 & & 820 & \\
\hline LSD $5 \%$ & 900.99 & & 85.58 & & 87.58 & & 6.724 & \\
\hline
\end{tabular}

J2: number of second stage juvenile in soil

D.S: number of developmental stages inside the roots

Reduction: $\mathbf{R} \%=$ Nematode number in control_-_nematode number in treatment

Nematode number in control

1:recommended dose of the compound $\quad 2: 1 / 10$ of the recommended dose

Data in Table (4) showed that highest effect refer to the treatment with ethoprop at recommended dose followed by oxamyl .Also, the crude compound Garnew gave a decrease in root knot nematode on peach seedling compared with the treatment of ethoprop and oxamyl at low concentration (1/10 recommended dose) and untreated control .

Table ( 5 ) : Effect of some treatments on development of Meloidogyne

\begin{tabular}{|c|c|c|c|c|c|c|c|c|}
\hline Treatments & $\mathrm{J} 2 / 250 \mathrm{~cm}^{3}$ soil & $\mathbf{R} \%$ & $\begin{array}{c}\text { No. } \\
\text { Galls/ } \\
\text { root }\end{array}$ & $\mathbf{R} \%$ & $\begin{array}{c}\text { egg- } \\
\text { masses/ } \\
\text { root }\end{array}$ & $\mathbf{R} \%$ & $\begin{array}{l}\text { No. } \\
\text { D.S } \\
\text { /root }\end{array}$ & $\mathbf{R} \%$ \\
\hline Ethoprop1 & 200 & 83.3 & 300 & 72.7 & 321 & 65.5 & 117 & 81.06 \\
\hline Ethoprop2 & 500 & 58.3 & 370 & 66.4 & 352 & 62.2 & 169 & 72.7 \\
\hline Oxamyl1 & 280 & 76.7 & 341 & 69.0 & 372 & 60 & 92 & 85.1 \\
\hline Oxamyl2 & 520 & 56.7 & 380 & 65.5 & 416 & 55.3 & 131 & 78.8 \\
\hline Garnew 1 & 500 & 58.3 & 410 & 62.7 & 432 & 53.5 & 141 & 77.2 \\
\hline Garnew 2 & 600 & 50 & 460 & 58.2 & 466 & 49.9 & 154 & 75.1 \\
\hline Nematode & 1200 & & 1100 & & 930 & & 618 & \\
\hline LSD $5 \%$ & 97.671 & & 60.516 & & 6.751 & & 6.634 & \\
\hline
\end{tabular}

J2: number of second stage juvenile in soil

D.S: number of developmental stages inside the roots

Reduction : $\mathbf{R} \%=$ Nematode number in control-nematode number in treatment

Nematode number in control

1 :recommended dose of the compound $\quad 2: 1 / 10$ of the recommended dose

The nematicide protects the roots from nematode invasion which resulted in sharp reduction in the number of galls, egg-masses in roots, and juveniles in soil. The present results in Table (5) emphasized that the crude extract exhibited potential nematicidal activity against the root-knot nematode and improved growth criteria of vineyard and peach even at low concentrations. 
All the tested materials significantly suppressed root-galling, the number of egg-masses and subsequently the final population. However, the natural compound Gar- new seemed to have toxic action

The nematicidal effect of the tested natural compound may possibly be attributed to high contents of certain oxygenated compounds which are characterized by their lipophilic properties that enable them to dissolve the cytoplasmic membrane of nematode cells and their functional groups interfering with the enzyme protein

structure (Knoblock et al.,1989). The mechanisms of plant extracts action may include denaturing and degrading of proteins, inhibition of enzymes and interfering with the electron flow in respiratory chain or with ADP phosphorylation(Konstantopoulou et al., 1994).

Table ( 6 ) : Effect of Garnew and two nematicides on some growth parameters of Mit Gammer peach cultivar.

\begin{tabular}{|c|c|c|c|c|}
\hline Treatments & $\begin{array}{c}\text { Shoot length } \\
\text { Cm }\end{array}$ & $\begin{array}{c}\text { Shoot weight } \\
\text { gm }\end{array}$ & \begin{tabular}{|c} 
Root \\
weight gm
\end{tabular} & $\begin{array}{l}\text { No.of new } \\
\text { branches }\end{array}$ \\
\hline Infected plant $+\mathrm{N}_{+}$ & 88.3 & 53.7 & 40.1 & 3 \\
\hline Infected plant $+\mathrm{N}+$ & 78.7 & 45.3 & 35.7 & 3 \\
\hline Infected plant $+\mathrm{N}+\quad$ Oxamyl1 & 78.3 & 50.1 & 38.3 & 4 \\
\hline Infected plant $+\mathrm{N}+\quad$ Oxamyl2 & 69.7 & 39.3 & 28.7 & 3 \\
\hline Infected plant $+\mathrm{N}+\quad$ Garnew1 & 96.3 & 60.3 & 43.7 & 7 \\
\hline Infected plant+N+ Garnew2 & 89.1 & 49.7 & 39.3 & 7 \\
\hline Infected nematode plant & 45.1 & 21.7 & 13.3 & 2 \\
\hline Non-infected plant & 47.3 & 30.3 & 19.7 & 3 \\
\hline LSD 5\% & 5.6 & 3.4 & 4.5 & 1.6 \\
\hline
\end{tabular}

It is clear from the data in Table (6) that applying the nature compound Garnew at high rate $(8 \mathrm{~L} / \mathrm{feddan})$ recorded the highest shoot length and shoot and root weights. Also the number of new branches significantly was increased by $2.5 \%$ as compared with untreated plants. The lowest values of vegetative growth were associated with the treatment of nematode only without any treatment. Increasing ethoprop and oxamyl doses increased significantly root and shoot criteria. Nyczepir et al 2000 found that plant growth of peach cultivar Lovell was suppressed by both $M$. incognita and M. javanica.

Table ( 7 ) : Effect of Garnew and two nematicides on some growth parameters of Superior grape cultivar.

\begin{tabular}{|c|c|c|c|}
\hline Treatments & $\begin{array}{c}\text { Shoot length } \\
\mathrm{Cm}\end{array}$ & $\begin{array}{c}\text { Shoot weight } \\
\text { qm }\end{array}$ & $\begin{array}{c}\text { Root weight } \\
\text { qm }\end{array}$ \\
\hline Infected plant $+\mathrm{N}+$ & 58.6 & 30.5 & 20.3 \\
\hline Infected plant $+\mathrm{N}+$ & 46.6 & 28.7 & 18.1 \\
\hline Infected plant $+\mathrm{N}+\quad$ Oxamyl1 & 60.2 & 30.7 & 20.7 \\
\hline Infected plant $+\mathrm{N}+\quad$ Oxamyl2 & 45.0 & 25.3 & 17.3 \\
\hline Infected plant $+\mathrm{N}+\quad$ Garnew1 & 87.7 & 43.2 & 31.3 \\
\hline Infected plant+N+ Garnew2 & 75.2 & 40.7 & 29.1 \\
\hline Infected nematode plant & 33.7 & 12.3 & 15.3 \\
\hline Non-infected plant & 36.3 & 23.7 & 13.7 \\
\hline LSD 5\% & 2.23 & 4.8 & 4.16 \\
\hline
\end{tabular}


Data in Table (7) showed that the same trend of increasing in shoot length ,shoot and root weights of grape. The highest values recorded from Garnew treatments followed by ethoprop and oxamyl at the dose 1 and finaly the lowest treatment values was recorded with the ethoprop and oxamyl at the dose two.

Table (8) : Effect of Garnew and two nematicides on mineral accumulation of Leaf samples from peach cultivar Mit Gammer inoculaled with Meloidogyne incognita.

\begin{tabular}{|c|c|c|c|c|c|c|c|c|c|}
\hline \multirow[t]{2}{*}{ Treatments } & \multicolumn{9}{|c|}{$\begin{array}{l}\text { Concentration\% } \\
\text { concentration ppm }\end{array}$} \\
\hline & $\mathbf{N}$ & $\mathbf{P}$ & $\mathbf{K}$ & $\mathbf{M g}$ & $\mathbf{C a}$ & $\mathrm{Na}$ & $\mathbf{Z n}$ & Mn & $\mathbf{F e}$ \\
\hline Infected plant +N+ & 2.61 & 0.16 & 3.20 & 908.09 & 0.182 & 0.250 & 36.93 & 8.37 & 296.3 \\
\hline Infected plant $+\mathrm{N}_{+}$ & 2.53 & 0.15 & 2.20 & 905.68 & 0.126 & 0.241 & 25.81 & 7.69 & 282.1 \\
\hline Infected plant $+\mathrm{N}+$ Oxamyl1 & 2.76 & 0.23 & 3.00 & 908.09 & 0.172 & 0.259 & 25.54 & 7.63 & 297.2 \\
\hline Infected plant $+\mathrm{N}+$ Oxamyl2 & 2.73 & 0.22 & 2.77 & 901.56 & 0.144 & 0.213 & 25.40 & 7.48 & 280.3 \\
\hline Infected plant $+\mathrm{N}_{+}$Garnew1 & 2.57 & 0.16 & 4.15 & 1206.5 & 0.247 & 0.286 & 86.40 & 10.8 & 347.3 \\
\hline Infected plant+N+ & 2.45 & 0.18 & 3.08 & 909.43 & 0.209 & 0.259 & 26.80 & 8.77 & 315.4 \\
\hline Infected nematode plant & 2.20 & 0.15 & 2.89 & 806.84 & 0.107 & 0.222 & 24.62 & 6.73 & 252.7 \\
\hline Non-infected plant & 2.30 & 0.15 & 2.89 & 901.15 & 0.182 & 0.227 & 24.73 & 7.0 & 277.3 \\
\hline LSD 5\% & 0.41 & 0.01 & 0.43 & 15.1 & 0.08 & 0.006 & 2.62 & 1.2 & 2.883 \\
\hline
\end{tabular}

The obtained results in Table (8) showed that the uptake and accumulation of minerals by Mit Gammer leaves that reflected the improvement of plants according to the treatments comparing with nematode treated plants in some minerals

Table (9):Effect of Garnew and two nematicides on mineral accumulation of root samples from peach cultivar Mit Gammer inoculaled with Meloidogyne incognita.

\begin{tabular}{|c|c|c|c|c|c|c|c|c|c|}
\hline \multirow[t]{2}{*}{ Treatments } & \multicolumn{6}{|c|}{ Concentration $\%$} & \multicolumn{3}{|c|}{ concentration ppm } \\
\hline & $\mathbf{N}$ & $\mathbf{P}$ & $\mathrm{K}$ & Mg & $\mathbf{C a}$ & $\mathrm{Na}$ & $\mathbf{Z n}$ & Mn & $\mathrm{Fe}$ \\
\hline $\begin{array}{lll}\text { Infected } & \text { plant } & +\mathrm{N}+ \\
\text { Ethoprop1 } & & \\
\end{array}$ & 1.76 & 0.17 & 0.71 & 808.45 & 0.182 & 0.232 & 28.17 & 28.09 & 352.1 \\
\hline $\begin{array}{lll}\text { Infected } & \text { plant } & +\mathrm{N}+ \\
\text { Ethoprop2 } & & \\
\end{array}$ & 1.59 & 0.16 & 0.60 & 800.97 & 0.135 & 0.222 & 23.59 & 29.05 & 317.0 \\
\hline $\begin{array}{lll}\text { Infected } & \text { plant } & +\mathrm{N}+ \\
\text { Oxamyl1 } & & \\
\end{array}$ & 1.67 & 0.19 & 0.71 & 706.73 & 0.228 & 0.222 & 32.17 & 53.60 & 22.7 \\
\hline $\begin{array}{lll}\text { Infected } & \text { plant } & +\mathrm{N}+ \\
\text { Oxamyl2 } & & \\
\end{array}$ & 1.59 & 0.16 & 0.57 & 706.73 & 0.135 & 0.204 & 26.65 & 24.82 & 303.5 \\
\hline $\begin{array}{lll}\text { Infected } & \text { plant } & +\mathrm{N}+ \\
\text { Garnew1 } & & \end{array}$ & 1.82 & 0.22 & 0.67 & 1200.6 & 0.219 & 0.305 & 27.78 & 28.93 & 355.3 \\
\hline $\begin{array}{ll}\text { Infected } & \text { plant+N+ } \\
\text { Garnew2 } & \end{array}$ & 1.70 & 0.19 & 0.54 & 1106.4 & 0.219 & 0.277 & 26.56 & 25.72 & 336.4 \\
\hline $\begin{array}{l}\text { Infected nematode } \\
\text { plant }\end{array}$ & 1.16 & 0.14 & 0.37 & 701.11 & 0.163 & 0.204 & 24.03 & 44.18 & 218.7 \\
\hline Non-infected plant & 1.56 & 0. & 0.44 & 704.40 & 0.228 & 0.222 & 26.36 & 20.7 & 265.1 \\
\hline LSD 5\% & 0.08 & 0.012 & 0.02 & 12.2 & 0.003 & 0.003 & 3.31 & 3.2 & 2.955 \\
\hline
\end{tabular}

Our data in Table (9) showed that the roots of treated plants accumulated more $\mathrm{N}, \mathrm{P}, \mathrm{K}$ and small or minor elements than the untreated controls. Since the treated roots were heavier than those of the controls, this higher amount of nutrients is probably a consequence of an increased root 
system absorbing surface, although gall formation would have contributed significantly to the final root mass.

Table (10): Effect of Garnew and two nematicides on mineral accumulation of Leaf samples from grape cultivar Superior inoculated with Meloidogyne incognita.

\begin{tabular}{|c|c|c|c|c|c|c|c|c|c|}
\hline \multirow{2}{*}{ Treatments } & \multicolumn{6}{|c|}{ Concentration \% } & \multicolumn{3}{|c|}{ concentration ppm } \\
\hline & $\mathbf{N}$ & $\mathbf{P}$ & K & Mg & $\mathrm{Ca}$ & $\mathrm{Na}$ & $\mathbf{Z n}$ & Mn & $\mathrm{Fe}$ \\
\hline \begin{tabular}{|lll} 
Infected & plant & $+\mathrm{N}+$ \\
Ethoprop1 & & \\
\end{tabular} & 1.73 & 0.29 & 3.86 & 703.93 & 0.246 & 0.250 & 28.27 & 9.03 & 285.1 \\
\hline $\begin{array}{lll}\text { Infected } & \text { plant } & +\mathrm{N}+ \\
\text { Ethoprop2 } & & \\
\end{array}$ & 1.66 & 0.27 & 3.07 & 604.05 & 0.246 & 241 & 25.44 & 8.80 & 272.3 \\
\hline \begin{tabular}{|lll} 
Infected & plant & $+\mathrm{N}+$ \\
Oxamyl1 & & \\
\end{tabular} & 1.78 & 0.30 & 3.02 & 609.11 & 0.225 & 0.259 & 26.73 & 7.97 & 281.9 \\
\hline $\begin{array}{lll}\text { Infected } & \text { plant } & +\mathrm{N}+ \\
\text { Oxamyl2 } & & \end{array}$ & 1.65 & 0.28 & 2.55 & 508.24 & 0.219 & 213 & 23.13 & 7.89 & 75.7 \\
\hline plant $+\mathrm{N}+$ & 1.78 & 0.35 & 2.34 & 708.66 & 0.274 & 0.286 & 42.42 & 8.73 & 336.5 \\
\hline \begin{tabular}{|ll} 
Infected & plant $+\mathrm{N}+$ \\
Garnew2 & \\
\end{tabular} & 1.65 & 0.32 & 2.34 & 562.87 & 0.246 & 0.259 & 36.77 & 8.38 & 307.2 \\
\hline $\begin{array}{l}\text { Infected nematode } \\
\text { plant }\end{array}$ & 1.41 & 0.20 & 2.17 & 400.17 & 0.163 & 0.222 & 24.42 & 6.40 & 243.6 \\
\hline Non-infected plant & 1.60 & 0.32 & 2.57 & 405.94 & 0.181 & 0.247 & 24.67 & 6.55 & 265.7 \\
\hline LSD 5\% & 0.09 & 0.06 & 0.33 & 13.42 & 0.02 & 0.006 & 1.36 & 0.79 & 0.920 \\
\hline
\end{tabular}

Most elements were within sufficiency levels ( Jones el al., 1991). Leaves of plants inoculated with the nematode alone were low in $\mathrm{N}$ and $\mathrm{Fe}$. The addition of nematicides and biofertilizer resulted in increased plant growth and gave the highest $\mathrm{Ca}, \mathrm{Fe}, \mathrm{Mg}, \mathrm{Mn}$ and $\mathrm{Na}$ values. Also, $\mathrm{P}$ and $\mathrm{K}$ increased with the addition of defferent treatments with some exceptions

Table (11) : Effect of Garnew and two nematicides on mineral accumulation of root samples from grape cultivar Superior inoculated with Meloidogyne incognita.

\begin{tabular}{|c|c|c|c|c|c|c|c|c|c|}
\hline \multirow[t]{2}{*}{ Treatments } & \multicolumn{6}{|c|}{ Concentration \% } & \multicolumn{3}{|c|}{ concentration ppm } \\
\hline & $\mathbf{N}$ & $\mathbf{P}$ & $\mathrm{K}$ & Mg & $\mathrm{Ca}$ & $\mathrm{Na}$ & $\mathbf{Z n}$ & Mn & $\mathrm{Fe}$ \\
\hline $\begin{array}{l}\text { Infected plant }+\mathrm{N}+ \\
\text { Ethoprop1 }\end{array}$ & 0.95 & 0.26 & 1.21 & 804.8 & 0.219 & 0.289 & 40.03 & 20.95 & 335.4 \\
\hline $\begin{array}{l}\text { Infected plant }+\mathrm{N}+ \\
\text { Ethoprop2 }\end{array}$ & 0.85 & 0.24 & 1.10 & 709.59 & 0.209 & 0.286 & 38.98 & 20.58 & 297.3 \\
\hline $\begin{array}{l}\text { Infected plant }+\mathrm{N}+ \\
\text { Oxamyl1 }\end{array}$ & 0.95 & 0.24 & 1.14 & 701.85 & 0.217 & 0.286 & 39.85 & 20.86 & 15.3 \\
\hline $\begin{array}{lll}\text { Infected } & \text { plant } & +\mathrm{N}+ \\
\text { Oxamyl2 } & & \\
\end{array}$ & 0.94 & 0.21 & 0.78 & 690.85 & 0.200 & 0.277 & 31.02 & 19.59 & 89.7 \\
\hline $\begin{array}{lll}\text { Infected } & \text { plant } & +\mathrm{N}+ \\
\text { Garnew1 } & & \\
\end{array}$ & 1.25 & 0.33 & 1.65 & 902.11 & 0.293 & 0.350 & 70.3 & 26.06 & 344.5 \\
\hline $\begin{array}{ll}\text { Infected } & \text { plant+N+ } \\
\text { Garnew2 } & \\
\end{array}$ & 1.09 & 0.30 & 1.50 & 802.72 & 0.228 & 0.323 & 40.88 & 22.31 & 327.1 \\
\hline $\begin{array}{l}\text { Infected nematode } \\
\text { plant }\end{array}$ & 0.67 & 0.21 & 0.75 & 409.5 & 0.172 & 0.236 & 27.01 & 16.94 & 226.3 \\
\hline Non-infected plant & 0.83 & 0.24 & 1.00 & 505.39 & 0.200 & 0.268 & 30.75 & 17.39 & 255.1 \\
\hline LSD 5\% & 0.06 & 0.06 & 0.15 & 15.36 & 0.33 & 0.04 & 1.93 & 2.49 & 1.264 \\
\hline
\end{tabular}


Our findings in Table ( 11$)$ indicated that some nutrient elements decrease ( $N$ and $\mathrm{Fe}$ ) while others increase notably in leaf tissues $(\mathrm{Mg}, \mathrm{Mn}$, $\mathrm{Zn}$, and $\mathrm{Na}$ ) in nematode inoculated treatrnents. In the first case, absorption and transport of $\mathrm{Fe}$ and $\mathrm{N}$ to aerial parts would seem to be impaired by the destruction of the root cortical tissues caused by the nematode probably due to the loss of the capaciry for differential permeabiliry which reduces nutrient element transport (Kirkpatrick, 1964). In contrast, Mg, Mn, $\mathrm{Zn}$ and $\mathrm{Na}$, seem to be absorbed continuously and accumulate in leaf tissues as a result of reduced growth, thus their increasing concentration. The lower concentrations in leaf tissues of these same elements in treatment without the nematode is explained by a growth dilution effect (Kleinschmidt \& Gerdemann, 1972; Granger et al., 1983).

A similar pattern for these elements (increase in $\mathrm{Zn}, \mathrm{Mg}$, and $\mathrm{Mn}$ and reduction in $\mathrm{Fe}$ and $\mathrm{Cu}$ in foliar apple (Pinochet el al., 1993 a) in plants infected with nematode.

Protein profile of peach and vineyard infected with Meloidogyne spp.:

To find the biochemical differences between the infected and treated plants with Gar new and nematicides, total protein was extracted and electrophoresed on one dimension Sodium dodecyle sulphate, polyacrylamide gel electrophoresis (SDS-PAGE).

SDS-PAGE analysis of infected plants revealed a clear differences in the intensity of the same protein bands between the infected and treated plants.

Data presented in Fig. (1\& 2) showed the protein profile of plants infected with Meloidogyne incognita and treated with biofertelizer Gar new and nonfumegant nematicides ethoprop and oxamyl this reflected the possible physiological differences among the treatments. The present results are in harmony with those of Farahat et al 2012, who reported that treating infected plants with fertilizers improve the performance of infected plants by enabling them to recompense root losses of soluble sugars and total carbohydrate and brought phenol contents back to be almost near to those in untreated healthy plants, raising tannins content, diminishing root contents of amino acids to be around those in healthy plants.

This study was designed to evaluate the nematicidal activity of the organic compound from several family species of the Asteraceae on the rootknot nematode $M$. incognita in planta experiments clearly demonstrated that $J_{2}$ survival and reproduction rate of the nematode were significantly reduced on grape and peach compared to the nonamended treatment. other researchers found that the population density of Meloidogyne spp. was reduced when host plants were grown in soil amended with Chrysanthemum spp. or Artemisia, Mentha, Garlic and / or Marjoram the results of the present study regarding the effects of nematode parasitism on plant growth under artificial conditions may be are not in agreement with the results of other researchers under field conditions. Differences in the susceptibility of the plant cultivars or differences in environmental conditions could be responsible for this. Essential oils from several plant species have been shown to have nematicidal activity on root-knot nematodes in vitro and in soil This compound is easily used into organic, conventional and integrated control 
J. Plant Prot. and Path., Mansoura Univ., Vol. 4 (2), February, 2013

growing system. Given obvious benefits and government may consider it as a promoting practice

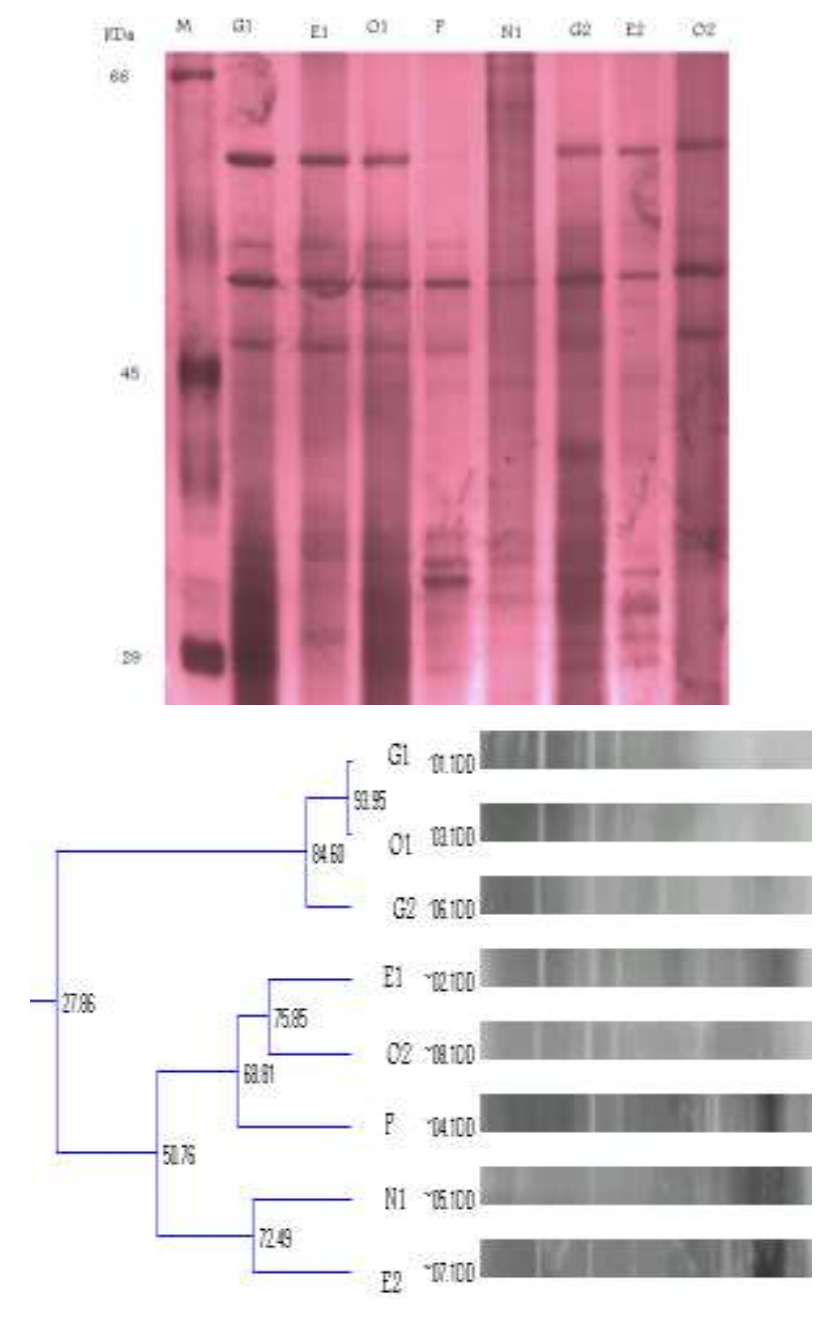

Fig. (1). Protein profile analysis and dendrogram of peach plants infected with Meloidogyne incognita using SDSpolyacrylamide gel electrophoresis stained with silver nitrate. 
Moatamed, A. M. H. and Hanaa S. Zawam
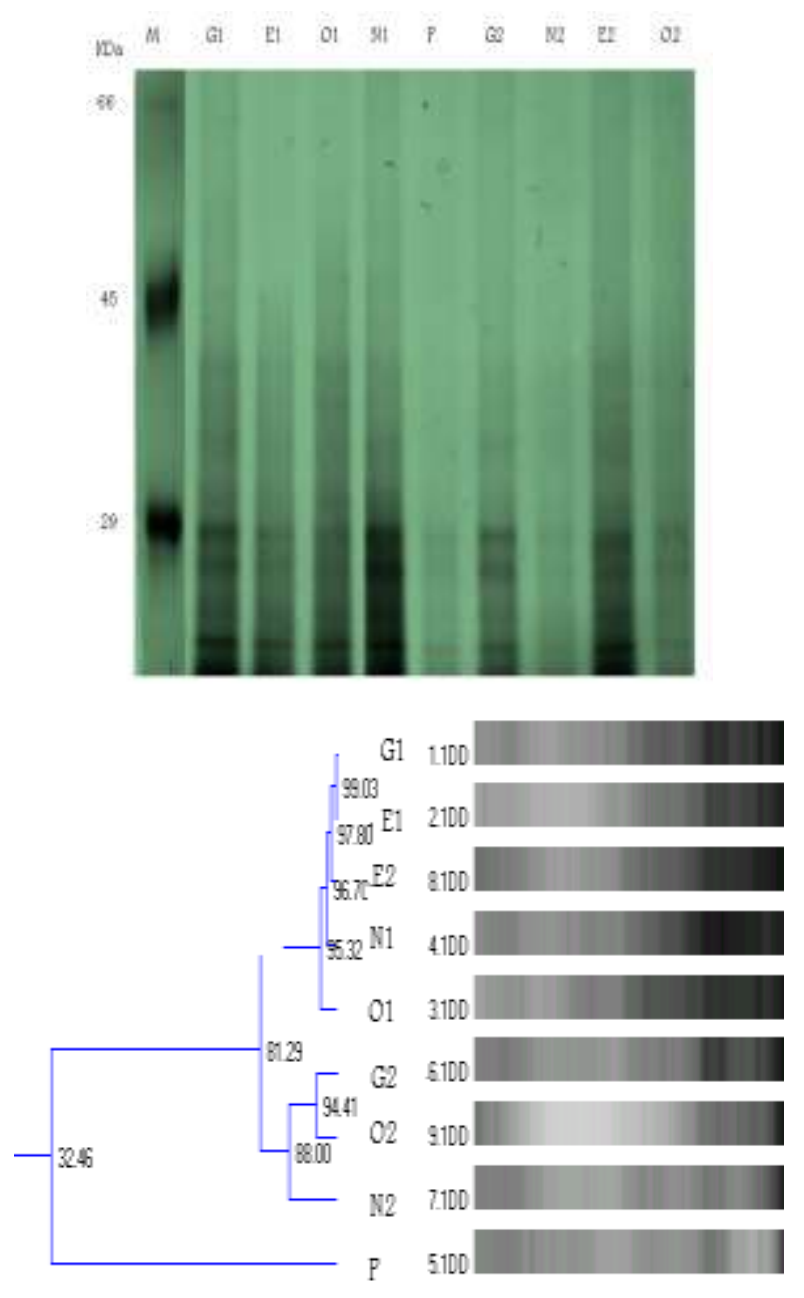

Fig. (2) :Protein profile analysis and dendrogram of grape plants infected with Meloidogyne incognita using SDSpolyacrylamide gel electrophoresis stained with silver nitrate.

\section{REFERENCES}

Alvarez-Castellanos P.P.; C.D. Bishop and M.J .Pascual- Villalobos , 2001. Antifungal activity of the essential oil of flowerheads of garland chrysanthemum (Chrysanthemum coronarium) against agricultural pathogens. Phytochemistry 57, 99-102. 
Bradford, M. 1976 "A Rapid and Sensitive Method for the Quantitation of Microgram Quantities of Protein Utilizing the Principle of Protein-Dye Binding" Anal. Biochem. 72:248-254.

Chapman, H. D. and F, Pratt (1981) Method of analysis for soil. Plant and Water Calif.Univ.USA.

Chatterjee A, Sukul NC, Laskar S, Ghoshma Jumdar S, 1982. Nematicidal principles from two species of Lamiaceae. Journal of Nematology 14, 118-20.

Chitwood DJ, 2002. Phytochemical based strategies for nematode control. Annual Review of Phytopathology 40, 221-49.

Farahat,A.A.; A. A. ALsayed; H. S. EL-beltagi; N.M. Mahfoud(2012)

Impact of Organic and Inorganic Fertilizers on Nematode Reproduction and Biochemical Alterations on Tomato. Notulae Scientia Biologicae $4(1): 48-55$

Gommers FJ, 1981. Biochemical interactions between nematodes and plants and the irrelevance to control: a review.Helminthological Abstracts (B) 50, 9-24.

Granger, R. L.; C. Plenchette and J.A.Fortin (1983). Effecr of vesiculararbuscular (VA) endomycorrhizal fungus(Glomus epigaeum) on the growth and leaf mineral content of two apple clones propagated in vitro. Canad. J. Pl. Sei., 63: 551-555.

Gupta, R. and Sharmaj, N.K. (1993). A study of the nematicidal activity of allicin-an active principle in garlic, Allium sativum L., against root-knot

nematode, Meloidogyne incognita. International Journal of Pest Management Volume 39, Issue 4, pages 390-392

Helrich, K. (ED).(1990) Official methods of analysis of the association of official analytical chemists. 2volumes

Arlington: AOAC, 1990. 15th ed. 2 volumes. $28 \mathrm{~cm}$. Book number: 7027

Jones,J. B., Wolf, B. and Mills, H. A. (1991). Plant analysis handbook. 1. Methods of planl analysis and Interpretation. Athens, GA, USA, MicroMacro Pub!., 213 p

Kirkpatrick,]. D. (1964). Interrelationships of plant nutrition, growth and plant parasitic nemarodes. In : Reuther, W. (Ed.). Plant analysis and fertilizer problems. Volume IV,American Institute of Biological Sciences, Washington DC, USA:189-225.

Kleinschmidt, G. D. and J. W. Gerdemann, (1972). Stunting of cirrus seedlings in fumigared nursery soils relared to the absence of endomycorrhizae. Phytopathology, 62 : 14471453

Knoblock, K.; Weis, N. and Wergant, R. 1989. Mechanism of antimicrobial activity of essential oils. 37th Ann. Cong. Med. Plant Res. Braunschweig, pp. 5-9.

Konstantopoulou, I.; Vassilopoulou, L.; Mawogantisi, Pidou P. and Scouras, G.

1994. Insecticidal effect of essential oils, A study of essential oils extracted from eleven Greek aromatic plants on Drosophila auroria. Experientia, 48: 616-619. 
Nyczepir, A.P. ;T.G. Beckman and G.L. Reighard (2000): Field evaluation of 'GUARDIAN' TM PEACH ROOTSTOCK TO DIFFERENT ROOT-KNOT NEMATODE SPECIES ISHS Acta Horticulturae 713: VI International Peach Symposium

Oka ,Y.; S. Nacar ; E. Putievsky ; U. Ravid ; Z. Yaniv and Y. Spiegel (2000): Nematicidal activity of essential oils and their components against the root -knot nematode. Phytopathology, 90: 710-715.

Pérez MP, Pascual-Villalobos MJ, 1999. Efectos del aceite esencial de inflorescencias de Chrysanthemum coronarium $\mathrm{L}$. en mosca blanca y plagas de almacén. Investigación Agraria: Producción y Protección Vegetal 14, 249-58

Pinochet,J.; A. Cambrvbi and C.Calvet, (1993 a). Effects of the root-lesion nematode Pralylenchus vulnus and the mycorrhizal fungus Glomlls mosseae on the growth of EMLA-26 apple rootstocks. Mycorrhiza, 4 : 79-83.

Ranganna, S (1979) Manual analysis of fruit and vegetable products. Data Magrow Hill Publishing Company Limited New Delhi 634p.

Sammons W. D.; L. D. Adams and E. E. Nishizawa (1981) Ultrasensitive silver-based color staining of polypeptides in polyacrylamide gels ELECTROPHORESIS Volume 2, Issue 3, pages 135-141, February 1981

Snedecor, G.W. and W.G. Cochran (1989): Statistical Methods. Eighth Ed. lowa: Blackwell Publishing.

Soler-Serratosa A, Kokalis-Burelle N, Rodríguez-Kábana R, Weaver C.F. and King P.S., 1996. Allelochemicals for control of plant-parasitic nematodes. 1. In vivo nematicidal efficacy of thymol and thymol/benzaldehyde combinations. Nematropica 26, 57-71.

Tomas, R. L.; Shearel, R. W. and Z. R. Mayer (1967) Comparison of conventional and automated producers for nitrogen, phosphorus and potassium analysis of plant material using single digestion. Agroni. J. 59: $240-243$.

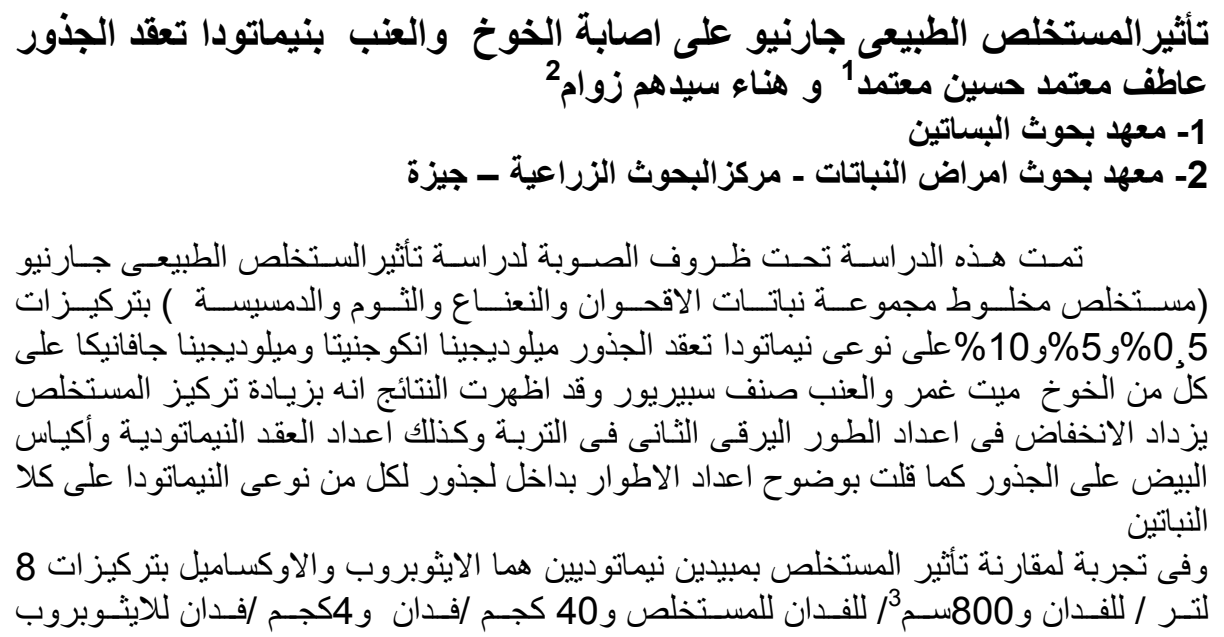




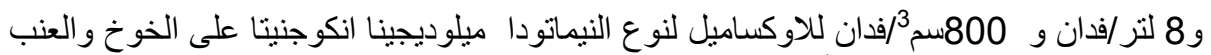

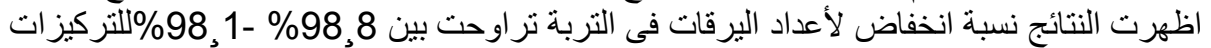

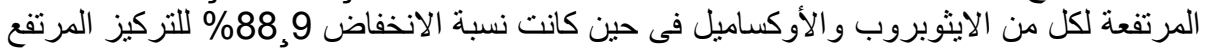

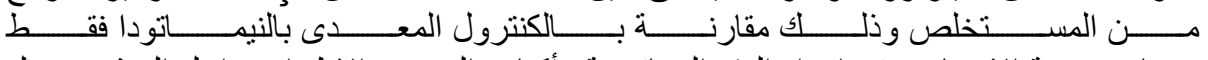

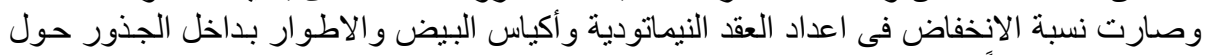

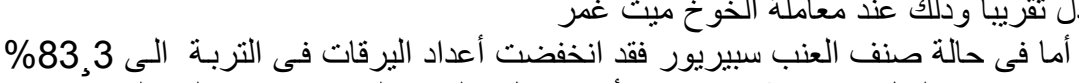

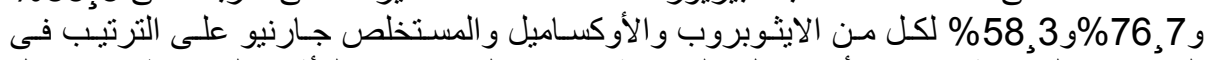

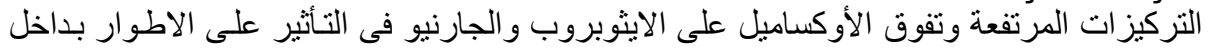

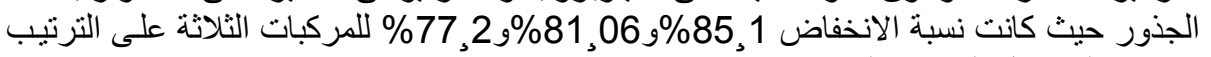

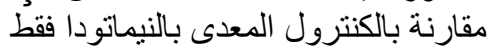

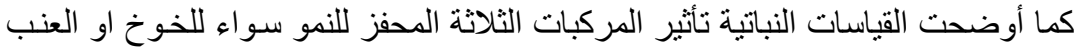

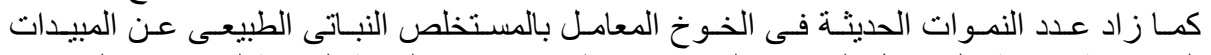

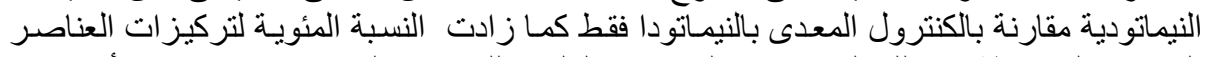

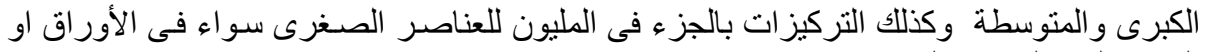
الجذور لكلا النوعين النباتيين

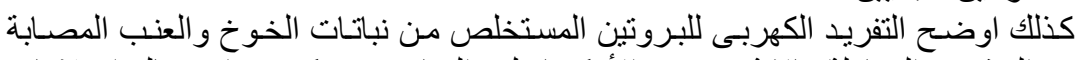

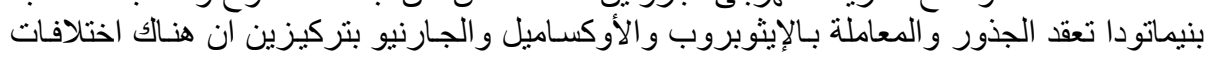

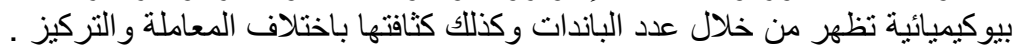

كلية الزراعة - جامعة المنصورة مركز البحوث الزراعية
قام بتحكيم البحث

أ.أد / عبد البديع عبد الحميد غانم

أ.د / محمود حسن الحموى عبد الحميد 